IJMS 25 (2), 91-109 (2018)

How to cite this article:

Ying, L. S. \& Harun, M. (2018). The Effects of Integrating Direct Cash Aid into Fuel Subsidy Removal on The Domestic Commodity Market in Malaysia by Using Computable General Equilibrium (CGE) Model. International Journal of Management Studies, 25(2), 91-109.

\title{
EFFECTS OF INTEGRATING DIRECT CASH AID INTO FUEL SUBSIDY REMOVAL IN THE DOMESTIC COMMODITY MARKET IN MALAYSIA USING COMPUTABLE GENERAL EQUILIBRIUM (CGE) MODEL
}

\author{
LOO SZE YING* \\ MUKARAMAH HARUN \\ School of Economics, Finance and Banking \\ Universiti Utara Malaysia \\ *Corresponding Author: szeyingloo89@gmail.com
}

\begin{abstract}
Direct cash aid has been introduced to protect the poor from the impact of rising fuel prices in efforts to remove subsidies in Malaysia. Thus, this paper is aimed at evaluating the changes in prices and quantities of consumer commodities produced by 17 sectors in response to the integration of direct cash aid into fuel subsidy removal. Specifically, the direct cash aid was a reallocation of saved resources through the complete removal of fuel subsidy. This study was carried out using the Lofgren-based computable general equilibrium (CGE) model, by simulating the before and after imposition of fiscal integration. With the withdrawal of government fuel subsidy, the findings showed that recipients of the cash aid tended to spend on basic necessities such as food and beverages, and petrol (for individual vehicle consumption). Nonetheless, the sudden increase in consumer expenditure led to higher consumer prices as current supplies was unable to catch up with increase in demand. Thus, it is advisable to have other effective, concurrent development programs to stimulate future economic development.
\end{abstract}

Keywords: Fuel subsidy removal, direct cash aid, computable general equilibrium (CGE) model.

Received: 7/8/2018 Revised: 23/4/2019 Accepted: 20/08/2019 Published: 15/12/2019 


\section{Introduction}

Fuel subsidy was one of the subsidies provided extensively by the Malaysian government to support the restructuring objectives of the National Economic Policy (NEP) and the National Development Policy (NDP). The fuel subsidy had led to some rapid major development goals such as economic growth, decreasing income inequality and significant reduction in poverty. Despite the relative merits, it raised questions as to whether the hidden costs of fuel subsidy had been taken into account. Enabling access to lower fuel prices had induced substantially uncontrollable fuel consumption which also concealed the fact of the risk of huge government resources that went only to fuel subsidy, crowding out other developmental spending.

The enormity of government resources that was placed on fuel over time had taken a heavy toll on public finances and it was even exaggerated when there was an extreme hike in global oil prices. Subsequently, fuel subsidy expenditures set a record highest point with RM20.3 billion or 13.0 percent of the operating expenditure on subsidies in 2008 on account of the sharp increase in world oil prices (Ministry of Finance, 2011). This had hugely burdened public finance, incurring high budget deficits. The overriding concerns of resolving this subject had led to the adoption of a market-based pricing mechanism for all fuel types. Domestic retailed prices for RON 95 fuel and diesel were all under the managed float system which was according to the monthly average global price of crude oil on 1 December 2014. Indeed, the government had removed its subsidy on RON 97 fuel in July 2010. Effective from end of March 2017, retail prices for all fuel types have been reviewed and determined on a weekly basis. Even though prices for RON 95 fuel and diesel remained at RM 2.20 and RM2.18 per litre, respectively for some time in order to stabilize fuel prices and reduce the cost of living of the people. These circumstances clearly demonstrated the government's intentions of removing all fuel subsidies to improve the fiscal budget.

The fiscal reform was expected to cause some unanticipated adverse impact on the domestic market due to the high reliance on fuel for domestic value-added economic activities. The fuel price hike would incur the burden of extra cost from direct and indirect channels to producers; producers would be directly impacted when fuel is directly used in production, and indirectly impacted when using nonfuel products with low consumer prices (Clements, Jung, \& Gupta, 2007; Rentschler, Kornejew, \& Bazilian, 2017). Usually, producers 
would prefer raising commodity prices to cope with the high input cost burden. Passing the extra cost burden on to end users would bring about high price levels in the market due to the spillover effects, exposing households to consumption loss, especially the low-income groups, and the poor who have high consumption rates and therefore would be vulnerable and greatly hurt (Arze del Granado, Coady, \& Gillingham, 2010; International Monetary Fund, 2013; Moshiri \& Santillan, 2018). This was exactly different from the previous era of low fuel prices where supplies of low-priced goods and services were accessible, keeping household consumption expenditure affordable. Several measures and incentives were then included to reduce the negative effects that hit the vulnerable groups, and one of them was direct cash aid targeting these groups.

The provision of direct cash aid was expected to temporarily minimize the effects on the current consumption of recipients, from the fiscal reform before any adjustments were made in their purchasing behavior. Despite the fuel price hike, the recipients had retained their purchasing behavior in accordance with their needs and desires. This raised a crucial issue of concern as to what extent the domestic commodity market would be impacted with the extra injection of cash into the market economy. The removal of fuel subsidy would bring higher costs of production and higher prices of goods and services as fuel is a critical element in the production and consumption baskets. It is not surprising that its removal always brings price increases, especially in the transition period. High price levels would lead to increased cost of living, which in turn, would weaken domestic purchasing power. Thus, direct cash aid has come to the fore on the grounds of mitigating measures.

This paper seeks to explain the market response of associating direct cash aid with complete fuel subsidy removal where changes in the prices and quantities of consumer commodities produced by 17 sectors were measured. To do that, a Malaysian computable general equilibrium (CGE) model with the base year of 2010 was constructed to simulate the relating fiscal shock. The structure of the paper is as follows. Selective empirical evidence related to the fiscal integration of fuel subsidy removal and direct cash aid are reviewed and discussed in Section 2. The research methodology is described in Section 3, including the research framework, model specifications, model closures, designed simulations, and data sources. In Section 4, changing prices and quantity of consumer commodities are estimated and compared with the base calibration year. The final section of the paper presents the conclusion. 


\section{Literature Review}

The idea of governmental intervention in stabilizing the economy had been widely promoted during the Great Depression in the 1930s. Appropriate government policies had stimulating effects on investments by sectors, which in turn, encouraged rising growth in national economic income (Abdullah, Mustafa, \& Habibullah, 2009; Said, Yusof, Said, \& Osman, 2010). More often than not, subsidies were integrated into the energy market to lower fuel prices with the aim of fostering economic development since fuel is a matter of utmost importance in input and consumption baskets. Despite this, numerous studies switched off focus on fuel subsidy on the basis of reaching sustainable economic growth in the long run, and concerns regarding undesirable consequences that covered matters such as promoting excessive and wasteful fuel consumption which was a main source of environmental pollution (Akinyemi, Alege, Ajayi, Adediran, \& Urhie, 2017; Clements et al., 2007; Feng, Hubacek, Liu, Marchán, \& VogtSchilb, 2018; IEA, OPEC, OECD, \& the World Bank, 2010; IMF, 2015; Mehmood \& Sadiq, 2010; Rentschler, Bleischwitz \& Flachenecker, 2018 ; Siddiq, Minor, Grethe, Aguiar, \& Walmsley, 2015). Often, fuel subsidies were encouraged to be removed completely and to move the subsidy-saving resources to other well-designed plans (Clements, et al., 2007; IEA, OPEC, OECD, \& the World Bank, 2010; IMF, 2015).

The complete removal of fuel subsidies would cause a spike in price level in the short term, severely aggravating domestic consumption that cannot be got rid of. A rise in real oil prices would have a noticeable impact on inflation (Wong, 2010). In this regard, a number of studies placed emphasis on the immediate reallocation of savings of direct cash aid which was a direct assistance to recipients to help them out temporarily from the high prices that hit them (Breisinger, Engelke, \& Ecker, 2012; Cockburn, Robichaud, \& Tiberti, 2018; Sayed, Sayegh, Saliba, \& Stephen, 2015; Siddig et al., 2015; Rentschler, 2016). For example, 20 percent of fuel subsidy savings was directed to the poorest residents in Lebanon, considering high price levels would become less pronounced over a period of five to 10 years (Sayed et al., 2015).

This aid does diminish consequential high price effects on resident incomes, and it does not sufficiently promote sustainable economic growth under the subsidy reform (Breisinger et al., 2012; Hamid, \& Rashid, 2012; Rentschler, 2016; Siddig et al., 2015). Take an empirical example, Siddig et al. (2015) found that the reallocation of savings 
to household transfers had minimal impact on increasing domestic production (only 9.6 percent increase) in comparison with another allocation to local refineries (domestic production increased at the rate of 47.4 percent). Nonetheless, they underlined the remarkable impact of this aid with 0.68 percent increase in private consumption expenditure on average, especially for those who lived in rural areas. This feature made this cash transfer more favorable to be imposed in the short term of the policy reform.

So far, studies on direct cash aid which focused their impact on market responses have remained sparse to sufficiently reflect their impact on changing prices and quantity demands in commodities. Few studies such as Breisinger et al. (2012), Siddig et al. (2015) and Rentschler (2016) empirically tested the effects that this cash transfer would likely have on domestic production, and some analyzed the effects using the qualitative method. For example, Ahmad, Rohana and Jamiliah (2013) estimated the effects of providing assistance via the previous 1Malaysia People's Aid scheme, a kind of direct cash aid on recipients' consumption patterns, using questionnaires. To fill the gap, this paper only focused on the potential impact that this cash transfer may have had on the prices and quantities of commodities by sectors in the short term of the subsidy reform. In the case of Malaysia, it was still considering the newly imposed subsidy reform in December 2014. The CGE model is considered a preferable analytical tool on this subject in contrast to the application of multiplier analysis of input-output by Fuad and Puasa (2011) and the social accounting matrix by Yahoo, Rashid, Kiaeeha and Chatri (2017). The CGE model includes equilibrium in the markets of factors, products and institutions in a single framework, by taking the fluctuating variables of prices and quantities into account. In this regard, Yahoo et al. (2017) hardly recommended the implication of the CGE model to trace the impact of exogenous economic policies in the context of endogenous relative prices.

\section{Research Methodology}

A static CGE model was developed to evaluate changes in the prices and quantity of consumer commodities in response to the introduction of direct cash transfer in the subsidy reform. The CGE model was built following the International Food Policy Research (IFPRI) CGE modeling framework that takes specific characteristics of developing countries into consideration sufficiently well to represent Malaysia as 
one of them. Löfgren et al. (2012) originally developed and formulated the IFPRI CGE model to examine the policy analysis of food and trade issues in developing countries. Some assumptions and modifications were made in conjunction with the objectives of the study. Further simulations were then laid out under the conditions of prefect competitiveness, only relative price matters, and market-clearing conditions existed for all markets. The model was structured on a set of mathematical equations where all economic behaviors (such as the ad valorem tax and the subsidy rate) were in fixed coefficients. All economic behaviors were captured by utility and profit maximization and subjected to a set of model constraints, based on nonlinear firstorder conditions. The General Algebraic Modeling System (GAMS) was used to run and solve the model.

The characteristic of the specific model in separating activities and commodities permitted any activity which was able to produce more than one commodity and any commodity which was able to be produced by more than one activity. At the production stage, to achieve greater profits, producers (activities) had to make some important decisions to include the factors' combination to equal the marginal revenue product and wages, and well-combined inputs between factors and intermediate inputs subject to a set of production technologies. With regard to all the aggregated outputs that entered the markets, the decision on output allocation to export and domestic markets was made subject to the constant elasticity of transformation (CET) function. The supply price and the local price paid were equal in the domestic market (excluding marketing costs). Meanwhile, export demands were infinitely elastic at a given world price where prices were measured in local currency.

Households, firms, the government and the rest of the world (ROW, the foreign sector) were institutions in the model. Both households and firms earned their income mainly from factors and transfers from other institutions. Households allocated their income to consumption, savings, diversified tax payments, and occasionally, transfers to other institutions. Firms did not consume, but they allocated their income to direct tax payments, saved some portions, and transferred to other institutions. For the government, receiving diversified tax payments was its main income source, together with transfer payments from other institutions. These public resources were then allocated wisely to consumption, subsidies and transfers to other institutions to avoid the crowding-out of resources from occurring. For the ROW, all trade and transfer payments from or to the foreign sector were fixed in 
foreign currencies. Thus, current account equilibrium was gained by differencing foreign currency spending and receipt.

\section{Model Specifications}

The interaction mechanism of the economy was formulated and grouped into four main blocks (price block, production and trade block, institution block, and system constraint block) with some core equations written and discussed as follows.

\section{Price block}

Equation (1) is the gross revenue for producing an output unit. The composite price in Equation (2) is input expenditure on using imports and domestic outputs. Prices of exports and imports are expressed in Equations (3) and (4), respectively. The export prices cover export tax $\left(t e_{c}\right)$, world export prices ( $\left.p w e_{c}\right)$, and exchange rate (EXR); meanwhile, the import prices cover import tariff $\left(t m_{c}\right)$, world import prices $\left(p w m_{c}\right)$, and exchange rate (EXR). They are held to be constant as Malaysia is a small country (it does not have any impact on world prices).

$$
P A a=\sum_{c \in C} P X A C_{a, c} \bullet \theta_{a, c}
$$$$
a \in A
$$

$$
P Q_{c} \bullet\left(1-t q_{c}\right) \bullet Q Q_{c}=P D_{c} \bullet Q D_{c}+P M_{c} \bullet Q M_{c}
$$$$
c \in(C D \cap C M)
$$

(3) $P E_{C}=\left(1-t e_{c}\right) p w e \bullet E X R$

$$
c \in C E
$$

(4) $P M_{C}=p w m_{c} \bullet E X R\left(1+t m_{c}\right)$

$c \in C M$

\section{Production and trade block}

A two-level nested production function was employed in making production decisions in which Leontief and CES production functions were adopted at the top- and bottom-level ${ }^{1}$ production activities, respectively. Then, demands for aggregate intermediate inputs at the activity level are the Leontief functions in Equation (5).

(5) QINT $_{c, a}=i c a_{c, a} \bullet$ QINTAa

$a \in A, c \in C$

The bottom-level production activity was connected to intermediate inputs and aggregate value added. 
In Equation (6), the imperfect transformability for the domestic output allocation to exports and domestic sales is held and expressed by the constant elasticity of the transformation (CET) function. Next, the Armington function for composite supply is defined in Equation (7), where it is restricted to only imports and domestic outputs. The element of exponent $\rho$ is the transformation of the elasticity of substitution between the exports and domestic sales in Equation (6), and imports and domestic outputs in Equation (7).

$$
\begin{array}{ll}
Q X_{C}=\alpha_{c}^{t} \bullet\left(\delta_{c}^{t} \bullet Q E_{c}^{\rho_{c}^{t}}+\left(1-\delta_{c}^{t}\right) \bullet Q D_{c}^{\rho_{c}^{t}}\right)^{\overline{\rho_{c}^{t}}} & c \in(C E \cap C D) \\
Q Q_{c}=\alpha_{c}^{q} \bullet\left(\delta_{c}^{q} \bullet Q M_{c}^{-\rho_{c}^{q}}+\left(1-\delta_{c}^{q}\right) \bullet Q D_{c}^{-\rho_{c}^{q}}\right)^{-\overline{\rho_{c}^{q}}} & c \in(C M \cap C D)
\end{array}
$$

\section{Institution block}

This block brings out functions that connect all the income and expenditure transactions of the institutions discussed previously. To focus on the government's role, Equation (8) indicates the government's incomes that include factor incomes, various direct taxes and transfers from the ROW. The incomes were then distributed to consumption and transfers, as shown in Equation (9).

$$
\begin{gathered}
Y G O V=\sum_{i \in I N S D N G} T I N S_{i} \bullet Y I_{i}+\sum_{f \in F} t f_{f} \bullet Y F_{f}+\sum_{a \in A} t a_{a} \bullet P A_{a} \bullet Q A_{a}+\sum_{c \in C} t q_{c} \bullet P Q_{c} \bullet Q Q_{c} \\
+\sum_{c \in C E} t e_{c} \bullet p w e_{c} \bullet Q E_{c} \bullet E X R+\sum_{c \in C M} t m_{c} \bullet p w m_{c} \bullet Q M_{c} \bullet E X R \\
+\sum_{f \in F} Y I F_{g o v, f}+t r n s f f_{g o v, r o w} \bullet E X R
\end{gathered}
$$

(9) $E G O V=\sum_{c \in C} P Q_{c} \bullet Q G O V_{c}+\sum_{i^{\prime} \in I N S D N G} t^{t r n s f} r_{i, g o v} \bullet C P I$

Equation (10) assesses the total incomes accumulated among the institutions. Specifically, Equation (11) indicates the total household consumption expenditure.

$$
\begin{aligned}
& Y I F_{i, f}=\operatorname{shif}_{i, f} \bullet\left[\left(1-t f_{f}\right) \bullet Y F_{f}-{\text { trnsf } f_{\text {row }, f}} \bullet E X R\right] \quad \\
& \mathrm{HHOH}_{h}=\left(1-\sum_{i \in I N S D N G} \operatorname{shii_{i,h}}\right) \bullet\left(1-M P S_{h}\right) \bullet\left(1-\text { TINS }_{h}\right) \bullet Y I_{h} \quad h \in H
\end{aligned}
$$


IJMS 25 (2), 91-109 (2018)

\section{System constraint block}

Functions of all market equilibrium were categorized under this block. The equilibrium condition in Equation (12) balances the quantities supplied and demanded for each factor (constant) in the factor market. Equation (13) balances the quantities supplied and demanded for the composite commodity. Equation (14) displays the equilibrium in the current account, balancing the earning and spending of foreign exchange for the country. This is determined by only the flexible (real) exchange rate (EXR), leading to the assumption on constant foreign savings (FSAV) and trade deficit.

$$
\begin{aligned}
& \sum_{a \in A} Q F_{f, a}=\overline{Q F S}_{f} \\
& Q Q_{c}=\sum_{a \in A} Q I N T_{c, a}+\sum_{h \in H} Q H_{c, h}+Q G O V_{c}+Q I N V_{c}+q d s t_{c}+Q T_{c} \\
& \sum_{c \in C M} p w m_{c} \bullet Q M_{c}+\sum_{f \in F} t r n s f r_{r o w}, f=\sum_{c \in C E} p w e_{c} \bullet Q E_{c}+\sum_{i \in I N S D} t r n s f r_{i, r o w}+\overline{F S A V}
\end{aligned}
$$

\section{Model Closures}

This sub-section discusses the balance conditions of markets for the factors, the government, the ROW and saving-investment. In the factor market, the quantity of each supply factor was exogenous and mobile (activity-specific). Only economy-wide wages and activityspecific wages took place, where the former was exogenous to balance the activity of demand and the quantity supplied, and the latter was the multiplication of the wage distortion term and the economy-wide wage.

In the fiscal account, flexible fiscal savings and constant direct taxes were held at the point of equilibrium. The fiscal savings were gained by distinguishing the current revenues and expenditures of the government. It means that reducing government expenditure would increase public revenues, which, in turn, would be spent on any wellplanned project to increase the effectiveness of the fiscal policy. Thus, the additional savings from the subsidy removal would be placed in the program of direct cash aid (which is the focus of this paper) and allowed to be accessed. 
In the market equilibrium of saving-investment, the closure of the saving-driven investment was put on hold for all non-government institutions. Hence, the marginal propensity to save (MPS) was exogenous, and investment was flexibly adjusted to equal the savings value.

For the ROW, constant current-account balance and flexible exchange rate took place where the balance of the foreign sector was obtained by differencing foreign currency spending and receipt. To conduct a short-run analysis, the real exchange rate was assumed to be constant; thus, exports and imports played important roles in influencing market balance.

\section{Simulations}

Two simulations were formulated to evaluate the before and after of introducing direct cash aid during the transition period of removing fuel subsidy in Malaysia. All changes on price and quantity of consumer commodities following the policy shock were estimated under the same economic environment. The findings were then discussed and compared with the basic reference year of 2010.

In the first simulation, the government completely removed existing fuel subsidy without any mitigating measures. This policy was imposed by increasing the rate of sales tax in the petroleum refinery sector proportionate to the reduction in government expenditure on fuel subsidy. In the second simulation, the government was assumed to integrate direct cash aid into subsidy removal to maintain consumption levels of targeted households. The integrated transfer policy was the reallocation of savings by completely removing the fuel subsidies.

\section{Data Sources}

The CGE model with the base year of 2010 was set up by a social accounting matrix (SAM), shaped primarily by the latest input-output (IO) table. The CGE model followed the constructed SAM modeling framework, and thus, all coefficients and exogenous components were obtained from the SAM model exactly. All the data needed for constructing the SAM model were collected from various sources such 
as the Department of Statistics, Malaysia (DOSM), Economic Planning Unit (EPU) and many others where data with the same reference year were given priority. The SAM model used was structured by factors of capital and labor, 17 aggregated sectors, households, firms, the government, indirect tax, saving-investment and the ROW. Besides, it was somewhat different to the construction of SAM model in studies such as Hassan, Saari, Utit, Hassan and Harun, (2016) as well as Yahoo et al. (2017), in terms of the adoption of separating commodities and activities for the SAM model in this study. A total of 124 production sectors for activity and commodity in the $2010 \mathrm{IO}$ table were grouped into 17 sectors of activity and commodity which could be identified by products, based on the Malaysia Classification of Products by Activities (MCPA) 2009. Table 1 lists the 17 sectors that were grouped.

Table 1

List of sectors in Malaysia

\begin{tabular}{cl}
\hline No. & \\
\hline 1. & Agriculture and fisheries \\
2. & Mining and quarrying \\
3. & Manufacture of dairy products \\
4. & Manufacture of processed food \\
5. & Manufacture of food and beverages \\
6. & Manufacture of textiles and leather \\
7. & Manufacture of wood products \\
8. & Manufacture of materials \\
9. & Manufacture of electrical and electronics \\
10. & Manufacture of petroleum refinery \\
11. & Manufacture of rubber and chemical products \\
12. & Manufacture of tobacco, paper and print products \\
13. & Manufacture of machine, vehicles and others \\
14. & Energies \\
15. & Construction \\
16. & Transportation \\
17. & Services \\
\hline
\end{tabular}


IJMS 25 (2), 91-109 (2018)

\section{Findings and Discussion}

\section{Effects of Integrating Direct Cash Aid into Fuel Subsidy Removal on Prices of Consumer Goods and Services}

The impact of integrating direct cash aid into subsidy fuel removal was estimated by considering the changing prices and quantities of consumer commodities produced by the 17 sectors. With the withdrawal of the fuel subsidies, the changing prices and the quantities of all consumer commodity groups were then compared before and after further subsidy savings to direct cash aid. All of the sectors were ranked from high to low in terms of the changing values. Moreover, the effects of all changes were counted on the changing rate of the CPI and, thus, they were real values.

Table 2

Changing prices of consumer commodities before and after the implementation of direct cash aid (percent)

\begin{tabular}{lccl}
\hline \multicolumn{1}{c}{ Sector } & Before & After & Change \\
\hline $\begin{array}{l}\text { Manufacture of petroleum } \\
\text { refinery }\end{array}$ & 24.6 & 25.4 & 0.9 \\
$\begin{array}{l}\text { Manufacture of tobacco, paper } \\
\text { products and printing }\end{array}$ & 21.8 & 22.6 & 0.8 \\
$\begin{array}{l}\text { Manufacture of rubber and } \\
\text { chemical products }\end{array}$ & 22.5 & 23.2 & 0.7 \\
$\begin{array}{l}\text { Mining and quarrying } \\
\text { Manufacture of processed food }\end{array}$ & 28.2 & 28.8 & 0.6 \\
$\begin{array}{l}\text { Manufacture of electrical and } \\
\text { electronics }\end{array}$ & 27.0 & 27.6 & 0.6 \\
$\begin{array}{l}\text { Manufacture of dairy products } \\
\text { Manufacture of machine, }\end{array}$ & 25.5 & 26.1 & 0.5 \\
$\begin{array}{l}\text { vehicles and others } \\
\text { Services }\end{array}$ & 25.4 & 25.9 & 0.5 \\
$\begin{array}{l}\text { Manufacture of textiles and } \\
\text { leather }\end{array}$ & 10.4 & 10.9 & 0.5 \\
\begin{tabular}{l} 
Transportation \\
\hline
\end{tabular} & 25.5 & 26.0 & 0.5 \\
& 31.3 & 31.6 & 0.4 \\
\hline
\end{tabular}


IJMS 25 (2), 91-109 (2018)

\begin{tabular}{lccl}
\hline \multicolumn{1}{c}{ Sector } & Before & After & Change \\
\hline Agriculture and fisheries & 22.6 & 22.9 & 0.3 \\
$\begin{array}{l}\text { Manufacture of food and } \\
\text { beverages }\end{array}$ & 20.3 & 20.6 & 0.3 \\
Manufacture of wood products & 26.4 & 26.4 & 0 \\
Manufacture of materials & 33.4 & 33.4 & 0 \\
Energies & 300.0 & 300.0 & 0 \\
Construction & 10.8 & 10.8 & 0 \\
\hline AVERAGE VALUES & 34.4 & 34.8 & 0.4 \\
\hline
\end{tabular}

Source: Authors' own calculations.

In Table 2, re-injecting all subsidy savings into the economy through direct cash aid to targeted households leads to an increase in the prices of all consumer commodity groups with an average increase rate of 0.4 percent. The results showed a heavier effect on the prices of consuming petrol under the policy integration, albeit other commodity groups were also impacted considerably as well. Yet, there was no effect on the consumer commodities of wood, materials, energies and construction.

\section{Effects of Integrating Direct Cash Aid into Fuel Subsidy Removal on Quantities of Consumer Goods and Services}

In Table 3, greater effects are reflected in changes in the quantity of consumption of food and beverages, and petrol, with high increased rates of 0.04 and 0.05 percent, respectively, after the imposition of direct cash aid upon the withdrawal of fuel subsidy. This shows that the distribution of direct cash aid in the short term is a one-off payment and the recipients tend to spend it on necessary commodities such as food and petrol (for own-vehicle use). Besides, other consumer commodities such as agriculture and fisheries, mining and quarrying, electrical and electronics had only slight equivalent effects. They increased at only 0.01 percent after the direct-cash imposition. Nevertheless, the direct-cash imposition did not have an impact on the total average value of the changing quantities of all consumer commodities. 
IJMS 25 (2), 91-109 (2018)

Table 3

Changing quantities in consumer commodities before and after the implementation of direct cash aid (percent)

\begin{tabular}{|c|c|c|c|}
\hline Sector & Before & After & Change \\
\hline $\begin{array}{l}\text { Manufacture of } \\
\text { petroleum refinery }\end{array}$ & -7.66 & -7.61 & 0.05 \\
\hline $\begin{array}{l}\text { Manufacture of food and } \\
\text { beverages }\end{array}$ & 3.27 & 3.31 & 0.04 \\
\hline $\begin{array}{l}\text { Manufacture of electrical } \\
\text { and electronics }\end{array}$ & -1.65 & -1.64 & 0.01 \\
\hline Mining and quarrying & -13.47 & -13.46 & 0.01 \\
\hline Agriculture and fisheries & -2.80 & -2.79 & 0.01 \\
\hline $\begin{array}{l}\text { Manufacture of wood } \\
\text { products }\end{array}$ & -7.16 & -7.15 & 0 \\
\hline $\begin{array}{l}\text { Manufacture of machine, } \\
\text { vehicles and others }\end{array}$ & -2.84 & -2.84 & 0 \\
\hline $\begin{array}{l}\text { Manufacture of textiles } \\
\text { and leather }\end{array}$ & -1.12 & -1.11 & 0 \\
\hline Services & -0.31 & -0.31 & 0 \\
\hline Transportation & -5.58 & -5.58 & 0 \\
\hline $\begin{array}{l}\text { Manufacture of } \\
\text { processed food }\end{array}$ & -4.27 & -4.27 & 0 \\
\hline $\begin{array}{l}\text { Manufacture of dairy } \\
\text { products }\end{array}$ & -1.06 & -1.06 & 0 \\
\hline Manufacture of materials & -7.89 & -7.89 & 0 \\
\hline $\begin{array}{l}\text { Manufacture of rubber } \\
\text { and chemical products }\end{array}$ & -9.53 & -9.53 & 0 \\
\hline $\begin{array}{l}\text { Manufacture of tobacco, } \\
\text { paper products and } \\
\text { printing }\end{array}$ & -0.08 & -0.08 & 0 \\
\hline Construction & -0.20 & -0.20 & 0 \\
\hline Energies & -4.63 & -4.64 & -0.01 \\
\hline AVERAGE VALUES & -4.08 & -4.08 & 0 \\
\hline
\end{tabular}

Source: Authors' own calculations. 
IJMS 25 (2), 91-109 (2018)

\section{Conclusion}

Rising concerns for uneconomical fuel subsidy drove the Malaysian government to remove the subsidy. The transmission of high fuel prices to the economy often ends up with high inflation rates, hitting the low-income groups and the poor hard. Direct cash aid becomes an effective tool in enhancing recipients' purchasing power by directly adding to their nominal incomes. These recipients who generally have a substantial consumption rate were more likely to spend rather than keep cash as savings; thus severely distorting market prices where existing supplies can hardly cope with the sudden spike in consumption demand. These findings have been discussed and underlined in the empirical studies reviewed. Thus, direct cash aid is relatively suitable in the short term. Hence, the government should combine it with additional complementary mechanisms to mitigate resulting high distorted prices which would continue in the long term.

\section{References}

Abdullah, H., Mustafa, M. M., \& Habibullah, M. S. (2009). An investigation on trade openness, fiscal policy and economic growth in Malaysia: Using an ARDL bounds testing approach. International Journal of Management Studies, 16(2), 177-197. Retrieved from http://ijms.uum.edu.my/index.php/previousissues/147-international-journal-of-management-studies-ijmsvol-16-no-2-december-2009

Ahmad, R.R., Rohana, K., \& Jamaliah, M. K. (2013, April). Bantuan Rakyat Satu Malaysia (BR1M): Consumption pattern and the relationship between acceptances, perception towards government sincere incentives and political motives. Paper presented at 2nd International Islamic Business, Kuala Lumpur, Malaysia. Kuala Lumpur: International Islamic University Malaysia.

Akinyemi, O., Alege, P. O., Ajayi, O. O., Adediran, O. S., \& Urhie, E. (2017). A simulation of the removal of fuel subsidy and the performance of the agricultural sector in Nigeria using a dynamic computable general equilibrium approach. Covenant Journal of Business and Social Sciences, 8(1), 60-70.

Anouti, Y. F., \& Dahl, C. A. (2014). Rationalizing transport fuel pricing policies and effects on global fuel consumption, emissions, government revenues and welfare (Working Paper No.2014-01). Colorado: Colorado School of Mines. Retrieved from https://ideas.repec. org/p/mns/wpaper/wp201401.html 
Arze del Granado, J., Coady, D., \& Gillingham, R. (2010). The unequal benefits of fuel subsidies: A review of evidence for developing countries (IMF Working Paper No.WP/10/202). Washington, DC: International Monetary Fund.

Breisinger, C., Engelke, W., \& Ecker, O. (2012). Leveraging fuel subsidy reform for transition in Yemen. Sustainability, 4, 28622887. Doi: $10.3390 / \mathrm{su} 4112862$

Chandra, A., Laan, T., Lang, K., Liebert, T., \& Wooders, P. (2012). Reforming fossil-fuel subsidies to reduce waste and limit $\mathrm{CO}_{2}$ emissions while protecting the poor. Geneva: International Institute for Sustainable Development. Retrieved from https:// www.iisd.org/library/reforming-fossil-fuel-subsidies-reducewaste-and-limit-co2-emissions-while-protecting-poor

Clements, B., Jung, H.S., \& Gupta, S. (2007). Real and distributive effects of petroleum price liberalization: The case of Indonesia. The Developing Economies, 45(2), 220-237. Doi: 10.1111/j.17461049.2007.00040.x

Cockburn, J., Robichaud, V. \& Tiberti, L. (2018). Energy subsidy reform and poverty in Arab countries: A comparative CGEmicrosimulation analysis of Egypt and Jordan. Review of Income and Wealth, 64(1), 1-31. Doi: 10.1111/roiw.12309

Dabla-Norris, E., Kochhar, K., Suphaphiphat, N., Ricka, F., \& Tsounta, E. (2015). Causes and consequences of income inequality: A global perspective (IMF Staff Discussion Note No. 15/13). Washington, DC: International Monetary Fund. Retrieved from https://www.imf.org/en/Publications/Staff-Discussion-Notes/ Issues/2016/12/31/Causes-and-Consequences-of-IncomeInequality-A-Global-Perspective-42986

Department of Statistics Malaysia. (2010). Malaysia Input-output Tables, 2010. Putrajaya: Author.

Department of Statistics Malaysia. (2014). Malaysia Economic StatisticsTime Series. Putrajaya: Author.

Economic Planning Unit. (2010). Tenth Malaysia Plan 2011-2015. Kuala Lumpur: Percetakan Nasional Berhad.

Feltenstein, A. (2017). Subsidy reform and implications for social protection: An analysis of IMF advice on food and fuel subsidies (IEO Background Paper BP/17-01/02). Washington, DC: International Monetary Fund.

Feng, K. S., Hubacek, K., Liu, Y., Marchán, E., \& Vogt-Schilb, A. (2018). Managing the distributional effects of energy taxes and subsidy removal in Latin America and the Caribbean. Applied Energy, 225, 424-436. Doi: 10.1016/j.apenergy.2018.04.116 
Fuad, S. N. A., \& Puasa, A. F. (2011). National key economic area multiplier impact on Malaysian economy: An inputout analysis. International Journal of Management Studies, 18(Special Issue), 34-58. Retrieved from http://ijms.uum.edu. my/index.php/previous-issues/152-international-journal-ofmanagement-studies-ijms-vol-18-special-issue-june-2011

Hamid, K. A., \& Rashid, Z. A. (2012). Economic impacts of subsidy rationalization Malaysia. In Y.Wu, X. Shi, \& F. Kimura (Eds.), Energy market integration in East Asia: Theories, electricity sector and subsidies (ERIA Research Project Report 2011-17). Jakarta: Economic Research Institute for ASEAN and East Asia. Retrieved from http://www.eria.org/Chapter\%209-Economic\%20 Impacts $\% 20$ of $\% 20$ Subsidy $\% 20$ Rationalization $\% 20 \mathrm{in} \% 20$ Malaysia.pdf

Hassan, A. A. G., Saari, M. Y., Utit, C., Hassan, A., \& Harun, M. (2016). Estimating the impact of GST implementation on cost of production and cost of living in Malaysia. Jurnal Ekonomi Malaysia, 50(2), 15-30.

International Energy Agency (2013). Southeast Asia Energy Outlook 2013. Paris: Author.

International Energy Agency (2015). Southeast Asia Energy Outlook 2015. Paris: Author.

International Energy Agency, Organization of the Petroleum Exporting Countries, Organization for Economic Co-operation and Development, \& the World Bank. (2010). Analysis of the scope of energy subsidies and suggestions for the G-20 initiative. Washington, DC: World Bank. Retrieved from http:// documents.worldbank.org/curated/en/959281468160496244/ Analysis-of-the-scope-of-energy-subsidies-and-suggestionsfor-the-G-20-initiative

International Monetary Fund. (2013). Case studies on energy subsidy reform: Lessons and implications. Washington, DC: Author. Retrieved from https://www.imf.org/en/Publications/PolicyPapers/Issues/2016/12/31/Case-Studies-on-Energy-SubsidyReform-Lessons-and-Implications-Supplement-PP4743

Laderchi, C. R. (2014). Transitional policies to assist the poor while phasing out inefficient fossil fuel subsidies that encourage wasteful consumption. Washington, DC: World Bank.

Maipita, I., Jantan, M. D., Fitrawaty, \& Narimo, S. (2012). The impact of diverting of fuel subsidy to agricultural sector on poverty. CMU Journal of Economics, 16(1), 84-100. Retrieved from https:// www.tci-thaijo.org/index.php/CMJE/article/view/61215 
Mehmood, R., \& Sadiq, S. (2010). The relationship between government expenditure and poverty: A Cointegration analysis. Romanian Journal of Fiscal Policy, 1(1), 29-37. Retrieved from https://www. econstor.eu/handle/10419/59799

Ministry of Finance Malaysia. (2011). Economic Report 2010/2011. Putrajaya: Author.

Moshiri, S., \& Santillan, M. A. M. (2018). The welfare effects of energy price change due to energy market reform in Mexico. Energy Policy, 113, 663-672. Doi: 10.1016/j.enpol.2017.11.035

Rentschler, J. (2016). Incidence and impact: The regional variation of poverty effects due to fossil fuel subsidy reform. Energy Policy, 96, 491-503. Doi: 10.1016/j.enpol.2016.06.025

Rentschler, J., Bleischwitz, R., \& Flachenecker, F. (2018). On imperfect competition and market distortions: The causes of corporate under-investment in energy and material efficiency. International Economics and Economic Policy, 15(1), 159-183. Doi: 10.1007/s10368-016-0370-2

Rentschler, J., Kornejew, M., \& Bazilian, M. (2017). Fossil fuel subsidy reforms and their impacts on firms. Energy Policy, 108, 617-623. Doi: 10.1016/j.enpol.2017.06.036

Said, F., Yusof, Z., Said, S. M., \& Osman, A. F. (2010). Foreign investment, government expenditure, and economic growth in Malaysia. International Journal of Management Studies, 17(1), 1-18. Retrieved from http://ijms.uum.edu.my/index.php/ previous-issues/148-international-journal-of-managementstudies-ijms-vol-17-no-1-june-2010

Sayed, L. E., Sayegh, W., Saliba, E., \& Stephen, J. (2015). Fossil fuel subsidies in Lebanon: Fiscal, equity, economic and environmental impacts. Lebanon: United Nations Development Programme. Retrieved from http://climatechange.moe.gov.lb/viewfile. aspx?id=218

Sdralevich, C., Sab, R., Zouhar, Y., \& Albertin, G. (2014). Energy subsidies in the Middle East and North Africa: Lesson for reform. Washington, DC: International Monetary Fund.

Siddiq, K., Minor, P., Grethe, H., Aguiar, A., \& Walmsley, T. (2015). Impacts on poverty of removing import subsidies in Nigeria (Policy Research Working Paper No. WPS7376). Washington, DC: World Bank. Retrieved from http://documents.worldbank. org/curated/en/977601468180545927/Impacts-on-poverty-ofremoving-fuel-import-subsidies-in-Nigeria

Widodo, T., Sahadewo, G. A., Setiastuti, S. U., \& Chaerriyah, M. (2012). Energy market integration in East Asia: Theories, electricity sector and subsidies. In Wu, Y., Shi, X., \& Kimura, F. (Eds), 
Cambodia's electricity sector in the context of regional electricity market integration (ERIA Research Project Report 2011-17). Jakarta: Economic Research Institute for ASEAN and East Asia. Wong, H. T. (2010). Inflation in Malaysia. International Journal of Management Studies, 17(2), 73-104. Retrieved from http://ijms.uum.edu.my/index.php/previous-issues/150international-journal-of-management-studies-ijms-vol-17-no2-december-2010

Yahoo, M., Rashid, Z. A., Kiaeeha, M. M., \& Chatri, F. (2017). Constructing a social accounting matrix to address income distribution issues in Malaysia. International Journal of Management Studies, 24(1), 139-167. Retrieved from http://ijms. uum.edu.my/index.php/previous-issues/169-internationaljournal-of-management-studies-ijms-vol-24-no-1-june

Zuhrin, A. A., \& Sukumaran, T. (2014, November 22). Prices for RON 95 and diesel to be determined by float system. The Star Online. Retrieved from https://www.thestar.com.my

Zunaira, S. (2017, December 11). Review of automatic price mechanism for fuel likely. The Star Online. Retrieved from https://www. thestar.com.my 